\title{
Effects of deoxynivalenol and degradation enzyme on growth performance and immune responses in mule ducks
}

\author{
Y.H. Cheng ${ }^{1,5}$, M.H. Chang ${ }^{2}$, Y.A. Lin ${ }^{1}$, J.F. Wu ${ }^{3}$ and B.J. Chen ${ }^{4}$ \\ ${ }^{1}$ Department of Animal Science, National I-Lan University \\ \#1, Sheng-Lung Rd., I-Lan 260, Taiwan \\ ${ }^{2}$ Department of Veterinary Medicine, National Chai-Yi University \\ Chai-Yi, Taiwan \\ ${ }^{3}$ Division of Applied Biology, Animal Technology Institute Taiwan \\ Miaoli, Taiwan \\ ${ }^{4}$ Department of Animal Science, National Taiwan University \\ Taipei, Taiwan
}

(Received 10 October 2003; revised version 1 March 2004; accepted 9 April 2004)

\begin{abstract}
Effects of deoxynivalenol (DON) on growth performance and immune responses, and the efficiency of DON degradation enzyme (DDE) in mule ducks were investigated. A total of 140 mule ducklings was equally assigned to treatment groups of control (no DON, no DDE), toxin 1 (5 ppm DON, no DDE), toxin 2 (10 ppm DON, no DDE), trial 1 (5 ppm DON, $1.5 \mathrm{~kg} /$ ton DDE), trial 2 (5 ppm DON, $2.5 \mathrm{~kg} /$ ton DDE), trial 3 (10 ppm DON, $1.5 \mathrm{~kg} /$ ton DDE), and trial 4 (10 ppm DON, 2.5 $\mathrm{kg} /$ ton DDE). There were no significant differences in total feed intake, body weight gain, and feed efficiency among treatment groups. However, the $5 \mathrm{ppm}$ DON alone, $5 \mathrm{ppm}+1.5 \mathrm{~kg} / \mathrm{ton}$ DDE, and $10 \mathrm{ppm}+1.5 \mathrm{~kg} /$ ton DDE groups resulted in a significant higher heart, liver and pancreas weight than those of control group. Pathological lesions in visceral organ and blood biochemistry parameters alteration were observed in mule ducks of all the DON treatment groups. DON challenge also decreased number of macrophages harvesting from each duck, and a slight improvement could even be seen if DDE $2.5 \mathrm{~kg} /$ ton were added, as compared with control group. These results suggest that DON exhibited multiple-toxic characteristics, in terms of hepatotoxicity, cardiotoxicity, and immunotoxicity in ducks. The addition of DDE at 1.5 or $2.5 \mathrm{~kg} / \mathrm{ton}$ in diet have revealed a toxic-sparing effects in blood biochemistry parameters and immune functions.
\end{abstract}

KEY WORDS: deoxynivalenol, growth performance, immune responses, mule ducks

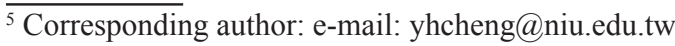




\section{INTRODUCTION}

Deoxynivalenol (DON, vomitoxin) is a mycotoxin of the type B trichothecenes, which are epoxy-sesquiterpenoids, found predominantly in grains such as wheat, barley and maize (Creppy, 2002).

Feeding trials with DON have demonstrated that poultry can tolerate up to 5 ppm dietary DON without deleterious effects (Trenholm et al., 1984). Moran et al. (1982) indicated that maize contaminated with Fusarium graminearum and containing 800 to $900 \mathrm{ppm}$ DON was subsitituted for control maize at $0-24 \%$ in a broiler ration, affected little on growth performance until the substitution exceeded 12\% (116 ppm DON). Male Leghorn chickens fed diets containing up to $18 \mathrm{ppm}$ DON to 35 day of age (Kubena et al., 1985) exhibited decrease haemoglobin and haematocrit levels. Administration of extremely high dose of 140-1120 ppm of DON to broiler chickens, however, caused symptoms including gasping, lethargy, dropping of the wings and head from normal upright position, loss of balance and death with $14 \mathrm{~h}$ (Huff et al., 1981). Post-mortem examination of the birds revealed ecchymotic haemorrhages throughout the gastrointestinal tract, liver, and necrotic lesions of the gizzard lining. Studies on feeding laying hens and growing chickens with contaminated maize showed that a level of 2-3 ppm DON did not produce any adverse effects on performance and the safe level of DON should be increased from 0.5 to $2-3 \mathrm{ppm}$ for poultry feed has been suggested (Muirhead, 1992). DON degradation enzyme (DDE) was fermentated from rumen microorganism, Eubacterium strain, which exhibits epoxidase, esterase, and deacetylation activity (Binder et al., 2000).

There were no available reference of duck-related research of DON challenge, and duck industry is an important poultry meat resource in Asia. The objective of this experiment was to investigate the growth performance, blood biochemical indices, and immune response of ducks, as affected by the different concentrations of DON added in diets, and the toxic alleviating effects of a kind of DDE.

\section{MATERIAL AND METHODS}

\section{Animals and experimental design}

A total of 140 one-day-old mule ducklings (Anas platyrhynchos $\times$ Cairina moschata) were obtained from a commercial hatchery and randomly assigned to seven dietary treatments. Birds were raised in electrically heated brooders with 10 ducklings per pen, 2 pens per treatment. Natural substrate contaminated with DON concentration of $1.5 \mathrm{~g} / \mathrm{kg}$, were incorporated into mash-form feeds as proportional as different treatments. The treatment groups were : control group (no 
DON, no DDE), toxin group 1 (5 ppm DON, no DDE), toxin group 2 (10 ppm DON, no DDE), trial group 1 (5 ppm DON, $1.5 \mathrm{~kg} /$ ton DDE), trial group 2 (5 ppm DON, $2.5 \mathrm{~kg} /$ ton DDE), trial group 3 (10 ppm DON, $1.5 \mathrm{~kg} /$ ton DDE), and trial group 4 (10 ppm DON, $2.5 \mathrm{~kg} /$ ton DDE).

The basal diet (Table 1) is primarily based on maize and soyabean meal, and was formulated according to Duck Nutrient Requirement Manual compiled by National Taiwan University (Shen, 1988). During the experiment, feed and water were provided ad libitum through the 3-week experimental period, and ducklings were daily observed for clinical signs. Birds were provided with $2 \mathrm{~m}^{2}$ of slotted floor space per pen with one drinker and hopper type feeder. Ambient temperature were kept between 22 to $30^{\circ} \mathrm{C}$. All experiments were conducted at animal testing farm, and the animal care and use were approved by National I-Lan University Experimental Animal Committee. Body weight gain, feed intake, and feed conversion by groups were recorded weekly through the experiment. Mortality was recorded whenever occurred.

TABLE 1

Composition of experimental diets

\begin{tabular}{lr}
\hline Indices & $\%$ \\
\hline Ingredients & 63.80 \\
maize & 24.50 \\
soyabean meal (CP44\%) & 3.00 \\
fish meal (CP60\%) & 5.00 \\
wheat bran & 0.60 \\
soyabean oil & 1.30 \\
dicalcium phosphate & 0.75 \\
limestone, pulverized & 0.30 \\
salt & 0.10 \\
L-Lysine & 0.07 \\
DL-Methionine & 0.08 \\
choline chloride, 50\% & 0.30 \\
vitamin premix & 1 \\
trace mineral premix ${ }^{1}$ & 0.20 \\
& \\
Calculated nutrient composition & \\
metabolizable energy, kcal/kg & \\
crude protein, \% & 2880 \\
sulphur amino acid, \% & 18.8 \\
available phosphorus, \% & 0.73 \\
calcium, \% & 0.50 \\
\hline
\end{tabular}

${ }^{1}$ diets contains per kg: vit.: A, 8000 IU; $\mathrm{D}_{3}, 1200 \mathrm{ICU}$; E, $10 \mathrm{IU}$ vit.; K, 2 mg: thiamin, 2; riboflavin, 5; pyridoxin, 0.2 ; vit. $\mathrm{B}_{12}, 0.03$; Ca-pantothenate, 10; niacin, 50; biotin, 0.1 ; folic acid, 0.5 ; choline, 300; Mn, 50; $\mathrm{Zn}, 60 ; \mathrm{Cu}, 10 ; \mathrm{Se}, 0.15 ; \mathrm{Fe}, 80$ 
At the end of the experiment, ducklings were sacrificed by cervical dislocation; relative weights of heart, liver, spleen and pancreas of four ducklings were obtained from each pen.

\section{Growth performance}

The body weights as well as feed intake of the ducks were monitored weekly, and body weigh gain, feed intake, and feed utilization efficiency were calculated. Mortality was recorded and the percentage was calculated after the end of the study.

\section{Macrophage chemotaxis and phagocytosis}

Phagocytotic assay follows a method described by Cheng et al. (2002). Briefly, the macrophage coverslip cultures were incubated with $2 \mathrm{ml}$ of Candida albican suspension $\left(1 \times 10^{7} \mathrm{ml}\right)$ in complete medium. After $60 \mathrm{~min}$ of incubation, the coverslips were washed with sterile saline, fixed in methanol, and then stained with May-Grunwald-Giemsa stain. The percentages of phagocytotic macrophages and average number of internalized Candida albican per phagocytotic macrophage were determined by scoring stained coverslip cultures under microscope at $1000 \times$ magnification. A total of 200 macrophages were scored per coverslip from each treatment of six ducks.

\section{Blood biochemical parameters and antibody titers}

Ducklings were vaccinated subcutaneously with $0.5 \mathrm{ml}$ of killed fowl cholera (FC) vaccine at three-day old, and booster in 2 weeks of age. Blood samples were taken weekly from four randomly selected ducklings for each treatment by cardiac puncture. A commercial test kit (IDEXX, MAINE, USA) was used to determine antibody titers of FC. Blood biochemical parameters were measured in serum samples obtained from four three-week-old ducklings per treatment. Serum was prepared from blood samples collected by cardiac puncture, and underwent a centrifugation of $2654 \times \mathrm{g}$ for $10 \mathrm{~min}$. Total bilirubin, aspartate aminotransferase (AST, EC 2.6.1.1), alanine aminotransferase (ALT, EC 2.6.1.2), and creatine kinase (CK, EC 2.7.3.2) were subsequently determined by automatic clinical chemistry analyser (Roche, Cobus-MiraPlus, Roche Diagnostic System Inc., USA).

\section{Examination of visceral pathology}

The heart, liver, spleen and pancreas were fixed in 10\% neutral formalin and embedded in paraffin. Sections were stained with haematoxylin and eosin (H\&E), and the sections were examined the histopathology alterations under light microscopy. 


\section{Statistical analysis}

Data were analysed using the General Linear Models procedure (SAS, 1988). The antibody titer was subjected to logarithmic transformation prior to analysis of variance. Differences between treatments means were determined by Duncan's new multiple range test.

\section{RESULTS}

No mortality was recorded throughout the duplicate experiments. In our pilot study results revealed that DDE were incorporated up to $2.5 \mathrm{~kg} / \mathrm{ton}$ in feeds did not altered growth performance and immune functions in mule ducks after 3 weeks feeding. Since, we focus on the DON toxicities and DDE benefit effects in this study. Effect of DON on growth performance in three weeks of age of mule ducks was summarized in Table 2. No significance differences were found in total feed intake, body weight gain, and feed efficiency among treatment groups. A tendency of declining feed intake was observed in the treatment of $10 \mathrm{ppm}$ DON plus $1.5 \mathrm{~kg} /$ ton or $2.5 \mathrm{~kg} / \mathrm{ton}$ DDE. The results also revealed that mule ducks showed a high tolerance to DON challenge at a level of $10 \mathrm{ppm}$.

TABLE 2

Effect of DON on growth performance in three weeks of age of mule ducks

\begin{tabular}{ccccc}
\hline \multicolumn{2}{c}{ Treatment } & & Total feed intake \\
DON & DDE & & $\begin{array}{c}\text { Body weight gain } \\
\mathrm{kg}\end{array}$ & $\begin{array}{c}\text { Feed efficiency } \\
\text { feed/gain }\end{array}$ \\
$\mathrm{ppm}$ & $\mathrm{kg} / \mathrm{ton}$ & & & \\
\hline 0 & 0 & $11.81 \pm 1.47$ & $4.58 \pm 0.35$ & $2.59 \pm 0.52$ \\
5 & 0 & $12.56 \pm 0.15$ & $4.54 \pm 0.31$ & $2.76 \pm 0.21$ \\
10 & 0 & $12.25 \pm 0.04$ & $4.47 \pm 0.53$ & $2.76 \pm 0.33$ \\
5 & 1.5 & $12.22 \pm 1.46$ & $4.05 \pm 0.27$ & $3.02 \pm 0.43$ \\
5 & 2.5 & $12.65 \pm 0.36$ & $4.16 \pm 0.34$ & $3.05 \pm 0.57$ \\
10 & 1.5 & $9.46 \pm 2.45$ & $4.38 \pm 0.42$ & $2.15 \pm 1.15$ \\
10 & 2.5 & $9.24 \pm 3.17$ & $4.24 \pm 0.63$ & $2.26 \pm 1.09$ \\
\hline
\end{tabular}

there were no significant difference among all treatment groups $(\mathrm{P}>0.05)$, all data were measured by groups basis as an average of 2 repetitions, and presented as means $\pm \mathrm{SD}$

In relative visceral organ weight, DON treatment and DDE addition did not alter the relative spleen weight. On the other hand, the $5 \mathrm{ppm}$ DON alone, $5 \mathrm{ppm}$ $+1.5 \mathrm{~kg} /$ ton DDE, $10 \mathrm{ppm}+1.5 \mathrm{~kg} /$ ton DDE groups resulted in a significant higher heart, liver and pancreas weight than control group (Table 3). These results can not specify the toxicity of DON on these organs, and no gross pathological lesions of visceral organ were observed in autopsy and only hypertrophy was evident. 
TABLE 3

Effect of DON on relative visceral organ weight of mule ducks

\begin{tabular}{ccccccc}
\hline \multicolumn{2}{c}{ Treatment } & & \multicolumn{4}{c}{ Relative organ weight, g/kg } \\
\cline { 1 - 2 } \cline { 5 - 7 } $\begin{array}{c}\text { DON } \\
\text { ppm }\end{array}$ & $\begin{array}{c}\text { DDE } \\
\mathrm{kg} / \text { ton }\end{array}$ & & $\begin{array}{c}\text { heart } \\
10^{-3}\end{array}$ & $\begin{array}{c}\text { liver } \\
10^{-2}\end{array}$ & $\begin{array}{c}\text { spleen } \\
10^{-3}\end{array}$ & $\begin{array}{c}\text { pancreas } \\
10^{-3}\end{array}$ \\
\hline 0 & 0 & & $8.04^{\mathrm{b}}$ & $3.10^{\mathrm{b}}$ & $1.24^{\mathrm{a}}$ & $5.08^{\mathrm{c}}$ \\
5 & 0 & & $9.37^{\mathrm{a}}$ & $4.35^{\mathrm{a}}$ & $1.46^{\mathrm{a}}$ & $8.70^{\mathrm{a}}$ \\
10 & 0 & & $8.15^{\mathrm{b}}$ & $3.34^{\mathrm{b}}$ & $1.23^{\mathrm{a}}$ & $6.73^{\mathrm{b}}$ \\
5 & 1.5 & & $9.38^{\mathrm{a}}$ & $4.73^{\mathrm{a}}$ & $1.19^{\mathrm{a}}$ & $7.65^{\mathrm{ab}}$ \\
5 & 2.5 & & $8.57^{\mathrm{ab}}$ & $3.34^{\mathrm{b}}$ & $1.36^{\mathrm{a}}$ & $6.52^{\mathrm{bc}}$ \\
10 & 1.5 & & $9.43^{\mathrm{a}}$ & $4.26^{\mathrm{a}}$ & $1.38^{\mathrm{a}}$ & $8.44^{\mathrm{a}}$ \\
10 & 2.5 & & $8.33^{\mathrm{ab}}$ & $2.97^{\mathrm{a}}$ & $1.14^{\mathrm{a}}$ & $6.41^{\mathrm{bc}}$ \\
Pool SE & & & 0.92 & 0.51 & 0.25 & 1.09 \\
\hline
\end{tabular}

$\overline{\text { a,b,c }}$ - means in the same column with different superscripts differ significantly $(\mathrm{P}<0.05)$, data presented as means $\pm \mathrm{SD}$

However, histopathological evidence indicated that there were different extent of vacuolization, pyknosis in hepatocytes (Figure 1), congestion or hyperaemia, and the blood vessels dilatation can be seen in focal area of heart (Figure 2). Cardiac muscle degeneration and necrosis were observed, and striation disappear were also noticed (Figure 3).

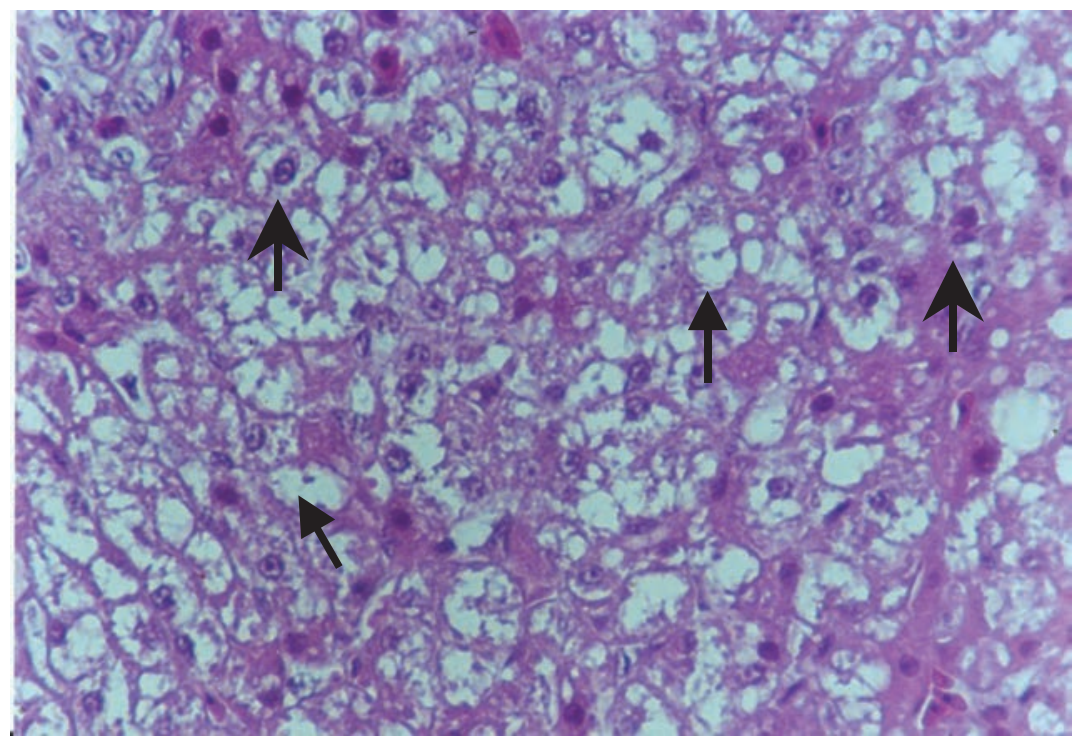

Figure 1. The effect of DON on liver histopathological alterations of mule ducks after 3 weeks challenge. Cytoplasmic vacuolization ( $\boldsymbol{\uparrow}$ ) and pyknosis ( $\boldsymbol{\uparrow}$ ) of duck hepatocytes were observed in DON $10 \mathrm{ppm}$ feeding group ( magnification of 1750X, HE stain) 


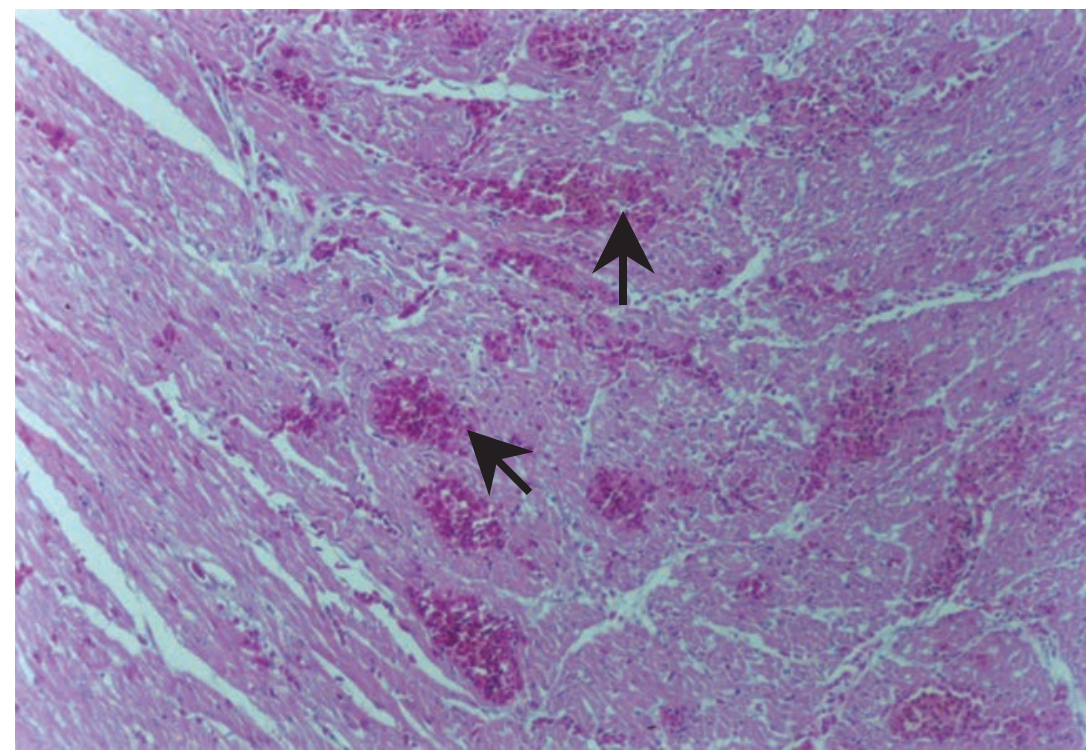

Figure 2. The effect of DON on histopathological alterations of mule ducks after 3 weeks challenge.

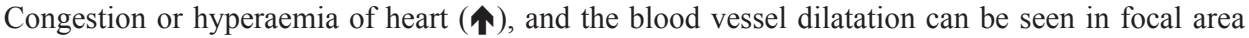
(magnification of 440X, HE stain)

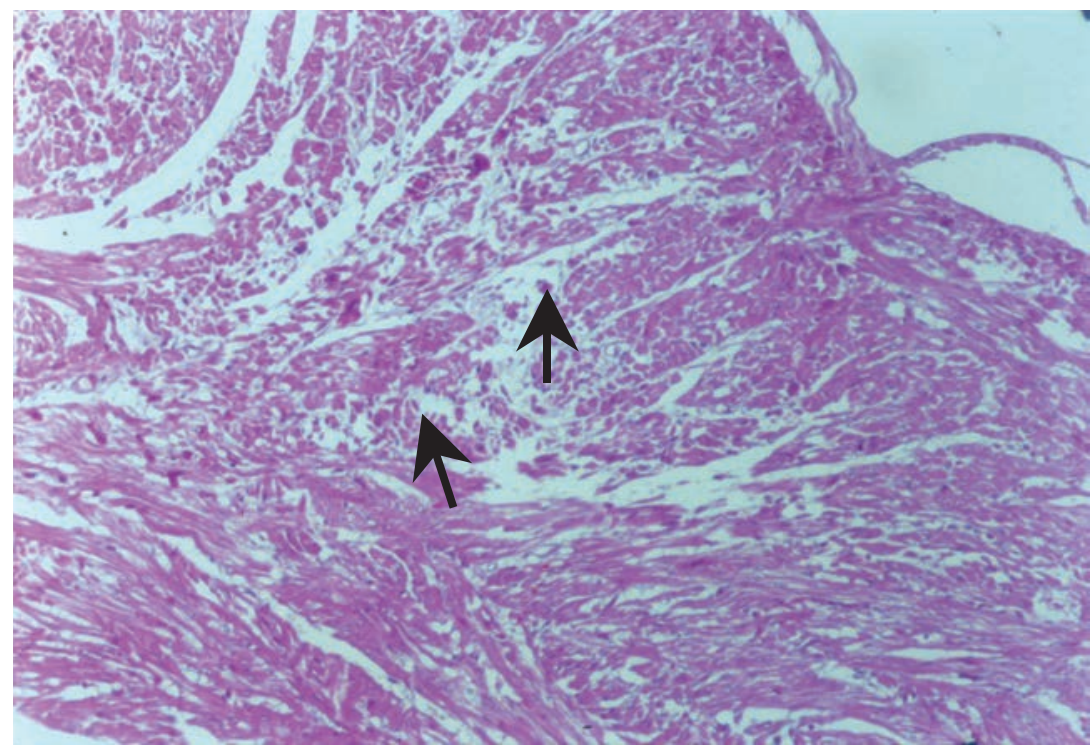

Figure 3. The effect of DON on histopathological alterations of mule ducks after 3 weeks challenge. Degeneration and necrosis of cardiac muscle striation disappear was observed ( $\mathbf{\uparrow})$ and rupture of cardiac muscle (magnification of 440X, HE stain) 
Table 4 summarized effect of DON on some parameters of serum biochemistry in mule ducks. Both of DON $5 \mathrm{ppm}+2.5 \mathrm{~kg} /$ ton DDE and control groups had the lowest total bilirubin, and DON $10 \mathrm{ppm}+1.5 \mathrm{~kg} /$ ton DDE showed the highest level of total bilirubin. In aspartate aminotransferase (AST) assay, DON $10 \mathrm{ppm}$ challenge, resulted the highest enzyme activity in serum, even through DDE at 1.5 and $2.5 \mathrm{~kg} /$ ton addition could not counteract this detrimental effect. This finding coincided with the histopathological outcome which revealed the hepatoxicity characteristics of DON. There was no significant difference among treatment groups of alanine aminotransferase (ALT) activity. However, creatine kinase (CK) activity showed the highest activity in DON $10 \mathrm{ppm}, 5 \mathrm{ppm}+1.5 \mathrm{~kg} / \mathrm{ton}$ DDE, and $10 \mathrm{ppm}+1.5 \mathrm{~kg} /$ ton DDE treatemnt.

TABLE 4

Effect of DON on some parameters of serum biochemistry in mule ducks

\begin{tabular}{|c|c|c|c|c|c|c|}
\hline \multirow{2}{*}{$\begin{array}{c}\mathrm{DON} \\
\mathrm{ppm}\end{array}$} & \multirow{2}{*}{$\begin{array}{c}\text { DDE } \\
\mathrm{kg} / \text { ton }\end{array}$} & \multirow{2}{*}{$\begin{array}{c}\text { Total } \\
\text { billirubin } \\
\text { mg/dl }\end{array}$} & \multirow{2}{*}{$\begin{array}{c}\text { Total } \\
\text { protein } \\
\mathrm{mg} / \mathrm{dl}\end{array}$} & AST & ALT & $\mathrm{CK}$ \\
\hline & & & & \multicolumn{3}{|c|}{$\mathrm{IU} / \mathrm{L}$} \\
\hline 0 & 0 & $0.68^{\mathrm{d}}$ & $3.53^{\mathrm{b}}$ & $17.5^{\mathrm{b}}$ & $28.8^{\mathrm{a}}$ & $897.5^{\mathrm{b}}$ \\
\hline 5 & 0 & $1.10^{\mathrm{ab}}$ & $3.93^{\mathrm{a}}$ & $25.7^{\mathrm{ab}}$ & $33.7^{\mathrm{a}}$ & $1306.0^{\mathrm{a}}$ \\
\hline 10 & 0 & $0.91^{\mathrm{bc}}$ & $4.05^{\mathrm{a}}$ & $54.6^{\mathrm{a}}$ & $30.8^{\mathrm{a}}$ & $875.8^{\mathrm{b}}$ \\
\hline 5 & 1.5 & $1.12^{\mathrm{ab}}$ & $4.15^{\mathrm{a}}$ & $22.8^{\mathrm{ab}}$ & $36.2^{\mathrm{a}}$ & $1255.4^{\mathrm{a}}$ \\
\hline 5 & 2.5 & $0.68^{d}$ & $3.86^{\mathrm{a}}$ & $23.3^{\mathrm{ab}}$ & $30.5^{\mathrm{a}}$ & $847.2^{\mathrm{b}}$ \\
\hline 10 & 1.5 & $1.21^{\mathrm{a}}$ & $4.01^{\mathrm{a}}$ & $21.6^{\mathrm{b}}$ & $30.5^{\mathrm{a}}$ & $1244.1^{\mathrm{a}}$ \\
\hline 10 & 2.5 & $0.76^{\mathrm{cd}}$ & $3.56^{\mathrm{b}}$ & $18.5^{\mathrm{b}}$ & $24.6^{\mathrm{a}}$ & $719.3^{b}$ \\
\hline Pool SE & & 0.03 & 0.05 & 26.6 & 10.6 & 258.0 \\
\hline
\end{tabular}

$\overline{\mathrm{a}, \mathrm{b}, \mathrm{c,d} \text { means in the same column with different superscripts differ significantly }(\mathrm{P}<0.05) \text {, data presented }}$ as means $\pm \mathrm{SD}$

AST: aspartate aminotransferase; ALT: alanine aminotransferase; CK: creatine kinase

TABLE 5

Effect of DON on peritioneal macrophage functions in three weeks of age of mule ducks

\begin{tabular}{|c|c|c|c|c|}
\hline \multicolumn{2}{|c|}{ Treatment } & \multirow{3}{*}{$\begin{array}{c}\text { No. of } \\
\text { macrophage/duck } \\
\text { No. } 10^{7} / \text { duck }\end{array}$} & \multirow{3}{*}{$\begin{array}{c}\text { No.of phagocytic } \\
\text { macrophages } \\
\%\end{array}$} & \multirow{3}{*}{$\begin{array}{c}\text { No. of Candida } \\
\text { /macrophages } \\
\%\end{array}$} \\
\hline DON & DDE & & & \\
\hline $\mathrm{ppm}$ & $\mathrm{kg} /$ ton & & & \\
\hline 0 & 0 & $2.94 \pm 0.25^{\mathrm{a}}$ & $29.19 \pm 5.75^{a}$ & $2.38 \pm 0.38^{\mathrm{a}}$ \\
\hline 5 & 0 & $1.44 \pm 0.29^{b}$ & $19.77 \pm 3.45^{\mathrm{ab}}$ & $1.83 \pm 0.37^{\mathrm{a}}$ \\
\hline 10 & 0 & $1.35 \pm 0.27^{\mathrm{b}}$ & $17.02 \pm 6.25^{b}$ & $1.22 \pm 0.28^{\mathrm{a}}$ \\
\hline 5 & 1.5 & $2.44 \pm 0.45^{\mathrm{ab}}$ & $24.38 \pm 1.32^{\mathrm{ab}}$ & $1.63 \pm 0.49^{\mathrm{a}}$ \\
\hline 5 & 2.5 & $3.17 \pm 0.38^{\mathrm{a}}$ & $29.48 \pm 5.27^{\mathrm{a}}$ & $1.75 \pm 0.66^{\mathrm{a}}$ \\
\hline 10 & 1.5 & $2.62 \pm 0.70^{\mathrm{ab}}$ & $20.75 \pm 0.90^{\mathrm{ab}}$ & $1.70 \pm 0.53^{\mathrm{a}}$ \\
\hline 10 & 2.5 & $2.83 \pm 1.01^{\mathrm{a}}$ & $28.15 \pm 1.49^{\mathrm{a}}$ & $1.68 \pm 0.50^{\mathrm{a}}$ \\
\hline
\end{tabular}

data presented as means \pm SD

a,b,c means in the same column with different superscripts differ significantly $(\mathrm{P}<0.05)$ 
Effect of DON on peritoneal macrophage functions in three weeks of age of mule ducks is showed in Table 5. It is interesting to note that DON challenge groups decreased number of macrophages harvesting from each duck, and an improvement can even be seen if DDE at $2.5 \mathrm{~kg} /$ ton was added, as compared with control group. Similar results also observed in number of phagocytic macrophages. These result confirmed that DDE 1.5 or $2.5 \mathrm{~kg} /$ ton can increase chemotaxis and phagocytic percentage which potentially hampered by DON. Meanwhile, there was no significant difference in number of Candida albican phagocytized by each macrophage.

There was no significance in antibody titers after fowl cholera challenge during 0 and 2 weeks of age as the effect of DON (Table 6). In the third week of age, DON $10 \mathrm{ppm}$ group significant decreased the FC antibody production, and DDE 1.5 or $2.5 \%$ addition gave a benefit effects which elevate antibody titer as compared with control group.

TABLE 6

Effect of DON on antibody titers against fowl cholera in mule ducks

\begin{tabular}{cllcl}
\hline \multicolumn{2}{c}{ Treatment } & & Week 2 & Week 3 \\
\cline { 1 - 2 } $\begin{array}{c}\text { DON } \\
\mathrm{ppm}\end{array}$ & $\begin{array}{c}\text { DDE } \\
\mathrm{kg} / \text { ton }\end{array}$ & Week 0 & & \\
\hline 0 & 0 & ND & $2.40 \pm 0.08^{\mathrm{a}}$ & $2.82 \pm 0.11^{\mathrm{a}}$ \\
5 & 0 & ND & $2.22 \pm 0.11^{\mathrm{a}}$ & $2.63 \pm 0.20^{\mathrm{ab}}$ \\
10 & 0 & ND & $2.28 \pm 0.15^{\mathrm{a}}$ & $2.55 \pm 0.24^{\mathrm{b}}$ \\
5 & 1.5 & ND & $2.24 \pm 0.16^{\mathrm{a}}$ & $2.77 \pm 0.12^{\mathrm{ab}}$ \\
5 & 2.5 & ND & $2.35 \pm 0.28^{\mathrm{a}}$ & $2.61 \pm 0.21^{\mathrm{ab}}$ \\
10 & 1.5 & ND & $2.33 \pm 0.15^{\mathrm{a}}$ & $2.68 \pm 0.19^{\mathrm{ab}}$ \\
10 & 2.5 & ND & $2.31 \pm 0.20^{\mathrm{a}}$ & $2.60 \pm 0.15^{\mathrm{ab}}$ \\
\hline
\end{tabular}

data presented as means $\pm \mathrm{SD}, \mathrm{ND}=$ not detected

$\mathrm{a}, \mathrm{b}$ means in the same column with different superscripts differ significantly at $\mathrm{P}<0.05$

\section{DISCUSSSION}

In our results of growth performance, lack of significant difference in feed intake and efficiency among treatments might result from lower birds repetition (2 repetitions in each treatment). However, tendency of feed intake decreased were observed as effect of DON supplementing. It is known that poultry are much less sensitive than pigs to DON, since levels as high as $8 \mathrm{ppm}$ in feeds had not been associated with impaired productivity (Hamilton, 1986). Rapidly growing broilers are generally more sensitive than laying hens to feed refusal (Huff et al., 1986). Feeding 75 ppm dietary DON to turkey poults from 7-14 day of age had no significant effect on feed consumption or growth rate (McMillian and Moran, 1985). In another trial, feeding a diet containing $4.4 \mathrm{ppm}$ DON to one day-old poults exert no effect on performance or mortality (Manley et al., 1988). 
Trichothecene mycotoxin, like DON, 12,13-epoxide ring responsible for binding protein synthesis at the translational level by binding at the large ribosomal subunit and subsequent inhibition of the inherent peptidyltransferase (Feinberg and McLaughlin, 1989). Since, the cells or tissues with higher protein turnover rates will be susceptible to DON. The DDE is a feed additive with adsorbing properties and epoxidase activities, which blocking epoxidase metabolites formation after DON metabolism in vivo. Epoxide metabolites of DON were account for binding ribosomal subunit (Pasteiner, 1988).

Based on the histological and blood biochemistry findings, it is proposed that the DON is a chemical of hepatotoxicity and cardiotoxicity in mule ducks. Trichothecenes, as DON cause histopathological lesion including cellular necrosis and karyorrhexis in actively dividing tissues of the intestinal mucosa, bone marrow, spleen, testis and ovary in experimental animals (Ciegler, 1978). Therefore, macrophages, lymphocytes, and erythrocytes may be decreased with prolonged exposure to trichothecenes. Haemolysis is also expected to be observed (Segal et al., 1983).

Blood plasma parameters might be used for an additional estimation of toxic effects on live birds. It is assumed that elevated activities of serum enzymes such as AST, ALT and total bilirubin might indicate recent organ damage (Cheng et al., 2001). In the studies of Kubena et al. (1988), there were no any effects observed on blood serum enzymes in chickens fed up to $16 \mathrm{ppm}$ DON feed. This difference maybe due to different animal species and the duration of DON challenge. However, our results showed that AST and CK activities were increased after DON exposure for 3 weeks in mule ducks. In histopathology observations also confirmed liver and heart muscle damages occurs (Figures 1-3), due to AST and CK often used to be a liver and heart trauma index.

Macrophages play crucial regulatory and effector roles in the immune system. Because macrophage function can be altered by a variety of stimulatory or suppressive signals, they are potential targets for feed and environmental toxicants (Cheng et al., 2002).

In macrophage functions evaluation, our results showed that DON was potentially harmful to bioactivities of macrophages. Similar results were also noticed by Muller et al. (1999), who reported that different trichothecenes (DON and T-2 toxin) combined to decrease the percentage of monocyte phagocytosis and increase percentage of PMN apoptosis in weaner pig. DON was observed to attenuate the immune response causing the restriction of the phagocytic and microbicidal activity of macrophages (Johannisson et al., 1999). Our results also revealed that nonspecific defense system will be hampered in mule ducks after DON challenge, and elevate the risk of pathogenic infection and disease breakout in the field.

Determination of serum titers to significant pathogens or vaccine after routine vaccination is a methodology, used to evaluate host immunocompetence effects of 
mycotoxins in vivo. Some reports indicated that DON was found to cause a dramatic elevation in total serum IgA in mice with concurrent decreases in total IgM and IgG (Forsell et al., 1986; Pestka et al., 1989). Although our data demonstrated that DON $10 \mathrm{ppm}$ did not change the level of antibody response after exposure for 2 weeks. However, the Ig production was decreased at the 3rd week, and consequently might be resulted in increasing susceptibility to pathogenic agents in ducks. Harvey et al. (1991) report demonstrated that NDV (Newcastle disease) antibody titers was decreased after feeding a DON-contaminated diet $(18 \mathrm{mg} / \mathrm{kg})$ to growing chickens for 18 weeks. Moreover, Danicke et al. (2002) indicated a significant decrease in NDV titers in hens fed on a Fusarium-contaminated feeds. Similar results were also observed that NDV titers were decreased after fed diets with up to DON $14 \mathrm{mg} / \mathrm{kg}$ to broilers (Danicke et al., 2003). Our outcomes coincide with Danicke et al. (2003) who stated approximately $10 \mathrm{ppm}$ of DON per $\mathrm{kg}$ was the lowest limiting levels negatively affected antibody response. Results showed that there were no counteract effects in FC titers by DDE addition at 5 and $10 \mathrm{ppm}$ DON concentrations in the present study.

\section{CONCLUSIONS}

In conclusion, DON at 5 or $10 \mathrm{ppm}$ did not alter the growth performance of mule ducks at 3 weeks of age. However, DON exhibited multiple-toxic characteristics, such as hepatotoxicity, cardiotoxicity, and immunotoxicity in ducks which were confirmed by histopathology, biochemistry and macrophage/antibody evaluation. Consumption of DON up to $10 \mathrm{ppm}$ did not cause overt clinical symptom. However, due to the sensitivity of the immune system to mycotoxin-induced immunosuppression arises from the stored cereal grains, and the most frequently found toxins were DON, T-2 toxin, and zearalenone in feeds. Therefore, it is necessary to monitoring the levels of mycotoxins in the grains from time to time. Our results also demonstrated that addition of DDE at 1.5 or $2.5 \mathrm{~kg} /$ ton in diet have revealed a toxic-sparing effects in blood biochemistry parameters and macrophage functions. 


\section{REFERENCES}

Binder E.M., Heidler D., Schatzmayr G., Thimm N., Fuchs E., Schuh M., Krska R., Binder J., 2000. Microbial detoxification of mycotoxins in animal feed. In: Proceedings of the 10th International IUPAC Symposium on Mycotoxins and Phycotoxins, Mycotoxins and Phycotoxins in Perspective at the Turn of the Millennium. Guaruja ( Brazil ), pp. 271-277

Cheng Y.H., Shen T.F., Pang Victor F., Chen B.J., 2001. Effects of aflatoxin and carotenoids on growth performance and immune response in mule ducklings. Comp. Biochem. Physiol. Pt C 128, 19-26

Cheng Y.H., Shen T.F., Pang Victor F., Chen B.J., 2002. Effect of Aflatoxin B1 on the function of peritoneal macrophage from mule duck. Asian-Austr. J. Anim. Sci. 15, 438-444

Ciegler A., 1978. Trichothecenes: Occurrence and toxicoses. J. Food Protect. 41, 399-403

Creppy E.E., 2002. Update of survey, regulation and toxic effects of mycotoxins in Europe. Toxicol. Lett. 127, 19-28

Danicke S., Matthes S., Halle I., Ueberschar K.H., Doll S., Valenta H., 2003. Effects of graded levels of Fusarium toxin-contaminated wheat and of a detoxifying agent in broiler diets on performance, nutrient digestibility and blood chemical parameters. Brit. Poultry Sci. 44, 113-126

Danicke S., Ueberschar K.H., Halle I., Matthes S., Valenta H., Flachowsky G., 2002. Effect of addition of a detoxifying agent to laying hen diets containing either non-contaminated or Fusarium toxin-contaminated maize on performance of hens and on carry-over of zearalenone. Poultry Sci. 21, 1671-1680

Feinberg B., McLaughlin C.S., 1989. Biochemical mechanism of trichothecene mycotoxins, In: V. R. Bcasley (Editor). Trichothecene Mycotoxicosis Pathological Effects. Boca Raton, FI, CRC Press. Vol. I, pp. 27-35

Forsell J.H., Witt M.F., Tai J.H., Jensen R., Pestka J.J., 1986. Effects of 8-week exposure of the B6C3F1 mouse to dietary deoxynivalenol (vomitoxin) and zearalenone. Food Chem. Toxicol. 24, 213-219

Hamilton R.M.G., Thompson B.K., Trenholm H.L., 1986. The effects of deoxynivalenol (vomitoxin) on dietary preference of White Leghorn hens. Poultry Sci. 65, 288-293

Harvey R.B., Kubena L.F., Huff W.E., Elissalde M.H., Phillips T.D., 1991. Haematologic and immunologic toxicity of deoxynivalenol (DON)-contaminated diets to growing chickens. Bull. Environ. Contam. Toxicol. 46, 410-416

Huff W.E., Doerr J.A., Hamilton P.B., Vesonder R.F., 1981. Acute toxicity of vomitoxin (deoxynivalenol) in broiler chickens. Poultry Sci. 60, 1412-1414

Huff W.E., Kubena L.F., Harvey R.B., Hagler W.M., Swanson S.P., Phillips T.C., Creger C.R., 1986. Individual and combined effects of aflatoxin and deoxynivalenol (DON, vomitoxin) in broiler chickens. Poultry Sci. 65, 1291-1298

Johannisson A., Bjokhag B., Hansson W., Gadhasson I.L., Thuvander A., 1999. Effects of four trichothecene mycotoxins on activation marker expression and cell proliferation of human lymphocytes in culture. Cell Biol. Toxicol. 15, 203-215

Kubena L.F., Huff W.E., Harvey R.B., Corrier D.E., Phillips T.D., Creger C.R., 1988. Influence of ochratoxin A and deoxynivalenol on growing broiler chicks. Poultry Sci. 67, 253-260

Kubena L.F., Swanson S.P., Harvey R.B., Fletcher O.J., Rowe L.D., Phillips T.D., 1985. Effects of feeding deoxynivalenol (vomitoxin)-contaminated wheat to growing chicks. Poultry Sci. 64, $1649-1655$

Manley R.W., Hulet R.M., Meldrum J.B., Larsen C.T., 1988. Turkey poult tolerance to diets containing deoxynivalenol (vomitoxin) and salinomycin. Poultry Sci. 67, 149-152

McMillian E., Moran E.T., 1985. Effect of feeding deoxynivalenol (DON) and zearalenone (F-2) to turkey poults. Poultry Sci. 64, 144 (Abstr.) 
Moran E.T. Jr., Hunter B., Ferket P., Young L.G., McGirr L.G., 1982. High tolerance of broilers to vomitoxin from corn infected with Fusarium graminearum. Poultry Sci. 61, 1828-1831

Muirhead S., 1992. Poultry found to tolerate high vomitoxin levels without ill effect. Feedstuffs 64 , 9-10

Müller G., Kielstein P., Rosner H., Berndt A., Heller M., Köler H., 1999. Studies on the influence of combined administration of ochratoxin A, fumonisin B1, deoxynivalenol and T2 toxin on immune and defense reactions in weaner pigs. Mycoses 42, 485-493

Pasteiner S., 1998. Mycotoxins in Animals Husbandry. Austria, Biomin Gesunde Tierernährung International GesmbH, Erber AG

Pestka J.J., Moorman M.A., Warner R.L., 1989. Dysregulation of IgA production and IgA nephropathy induced by the trichothecene vomitoxin. Food Chem. Toxicol. 27, 361-368

SAS Institute, Users Guide, 1988. Basics, Release 6.03 Edition, SAS Institute Inc., Cary, NC

Segal R.I., Milo-Goldzweig A., Joffe Z., Yagen B., 1983. Trichothecenes induced haemolysis. 1. The haemolytic activity of T-2 toxin. Toxicol. Appl. Pharmacol. 70, 343-349

Shen T.F. (Editor), 1988. Manual of Nutrient Requirements of Ducks. Department of Animal Science, National Taiwan University, Taipei (Taiwan)

Trenholm H.L., Hamilton R.M.G., Friend D.W., Thompson B.K., Hartin K.E., 1984. Feeding trials with vomitoxin (deoxynivalenol)-contaminated wheat: effects on swine, poultry, and dairy cattle. J. Amer. Vet. Med. Assoc. 185, 527-531

\section{STRESZCZENIE}

\section{Wpływ deoksynivalenolu i enzymu rozkładającego DON na wzrost i reakcję immunologiczną kaczek hybrydów}

Badano wpływ deoksynivalenolu (DON) i dodatku enzymu rozkładającego DON (DDE) na wzrost i reakcję immunologiczną kaczek - hybrydów. Sto czterdzieści kacząt - samców podzielono na następujące grupy: kontrolną (bez DON i DDE), toksyczną 1 ( 5 ppm DON, bez DDE), toksyczną 2 (10 ppm DON, bez DDE), doświadczenie 1 (5 ppm DON, 1,5 kg/tona DDE), doświadczenie 2 (5 ppm DON; 2,5 kg/tona DDE), doświadczenie 3 (10 ppm DON; 1,5 kg/tona DDE) i doświadczenie 4 (10 ppm DON; 2,5/tona DDE).

Nie stwierdzono statystycznie istotnych różnic w pobraniu paszy, przyrostach i wykorzystaniu paszy pomiędzy grupami. Jednak u kacząt otrzymujących 5 ppm DON bez dodatku oraz z dodatkiem DDE w ilości 1,5 kg/tona, a także otrzymujących 10 ppm DON z dodatkiem 1,5 kg DDE/tona, masa serca, wątroby i trzustki była istotnie większa niż u ptaków kontrolnych. U wszystkich kacząt otrzymujących DON stwierdzono patologiczne zmiany w narządach wewnętrznych oraz zmiany we wskaźnikach biochemicznych krwi. DON spowodował także zmniejszenie liczby makrofagów, wyizolowanych od każdego kaczęcia; przy uzupełnieniu diety 2,5\% DDE stwierdzono pewną poprawę w porównaniu z grupą kontrolną.

$\mathrm{Na}$ podstawie otrzymanych wyników można sądzić, że DON wykazuje wielotoksyczne właściwości, a mianowicie jest toksyczny dla wątroby, serca i uszkadza system odpornościowy u kaczek. Dodatek DDE w ilości 1,5 kg/tona paszy spowodował ograniczenie objawów toksycznych we wskaźnikach biochemicznych krwi oraz funkcjach odpornościowych. 